\title{
Future Economic Involvement of Indonesian Women in Postgraduate Education
}

\author{
Dinda Lisna Amilia \\ Mass Communication and Journalism, University of Mysore, India \\ *Email: dindaa007@gmail.com
}

\begin{abstract}
Indonesian women's enrollment in education is showing progress. According to the 2015 national census, $7.92 \%$ of the total female population chose to enter university. However, the question remains: what are the plans of Indonesian women with postgraduate education in terms of their involvement in the economy? This research used a qualitative descriptive method, distributing questionnaires to 55 respondents, 11 of whom were also interviewed. The primary reason for women to obtain a higher education is to keep their family economically stable. Therefore, they are willing to save money for postgraduate education, with the majority using private funds, and $84 \%$ of respondents said that they will continue to work after marriage. This paper suggests a link to the symptom stage of naïve consciousness, a theory developed by Paulo Freire. In terms of this theory, Indonesian women have yet to understand that they could be agents of social change in the era of the demographic bonus.
\end{abstract}

Keywords: education, women's education, women's contributions

\section{Introduction}

Indonesia's higher education sector has made progress in recent years, as seen in scholarships program such as Bidikmisi for undergraduate students, and LPDP for higher level students. These scholarships are intended to enhance the Indonesian demographic bonus, a situation where the country will have a large productive population, which is expected to occur by 2030.

When comparing data from 2010 with predicted data for 2035, the proportion of children aged 0-14 years out of the total population is expected to decline from $28.6 \%$ (2010) to $21.5 \%$ (2035). Meanwhile, the working age population, 15-64 years old, is expected to increase from $66.5 \%$ to $67.9 \%$, and people aged 65 years and above will rise from $5.0 \%$ to $10.6 \%$. This changing composition affected the dependency ratio, which fell from $50.5 \%$ (2010) to $47.3 \%$ in 2035 . The decline of the dependency ratio shows that the economic burden, where the productive age group has to bear the life cost of the unproductive population, is decreasing (BPS, 2015).

As shown in Table 1, the participation of women in higher education is increasing year by year. In the 2015 national census, the percentage of women who achieved a level of higher education reached 7.92\%. This was made up of $11.8 \%$ of the female urban population, and $3.86 \%$ of the rural female population.

Although the total percentage of rural women achieving higher education is lower than their urban counterparts, the numbers show a small yet consistent year-on-year improvement. However, urban women's participation in higher education declined twice, in 2011 and 2013. The difference in the rates of participation in higher education between women and men is not large and has not changed much over the years, which suggests relative gender equality in terms of access to higher education.

Table 1. Participation in Higher Education

\begin{tabular}{|l|l|l|l|l|l|l|l|l|}
\hline Area & Gender & \multicolumn{1}{|c|}{2009} & 2010 & 2011 & 2012 & 2013 & 2014 & 2015 \\
\hline \multirow{4}{*}{ Urban } & Male & 10.64 & 11.20 & 10.65 & 11.48 & 10.64 & 11.41 & 12.18 \\
\cline { 2 - 9 } & Female & 9.79 & 10.24 & 10.20 & 10.66 & 10.47 & 11.30 & 11.80 \\
\cline { 2 - 9 } & Total & 10.20 & 10.72 & 10.42 & 11.07 & 10.56 & 11.36 & 11.99 \\
\hline \multirow{5}{*}{ Rural } & Male & 2.79 & 2.95 & 2.89 & 3.09 & 2.94 & 3.25 & 3.58 \\
\cline { 2 - 9 } & Female & 2.59 & 2.90 & 3.04 & 3.12 & 3.29 & 3.59 & 3.86 \\
\cline { 2 - 9 } & Total & 2.69 & 2.92 & 2.97 & 3.10 & 3.11 & 3.42 & 3.72 \\
\hline \multirow{5}{*}{ Urban \& Rural } & Male & 6.67 & 7.12 & 6.79 & 7.37 & 6.86 & 7.41 & 7.98 \\
\cline { 2 - 9 } & Female & 6.13 & 6.62 & 6.67 & 6.96 & 6.94 & 7.52 & 7.92 \\
\cline { 2 - 9 } & Total & 6.40 & 6.87 & 6.73 & 7.16 & 6.90 & 7.46 & 7.95 \\
\hline
\end{tabular}

Source: Indonesian Central Bureau of Statistics (BPS) 
In addition, the data show that the Employment Participation Rate of women has improved, starting at $32.43 \%$ in 1980 and rising to $38.79 \%$ in 1990 and 50.22\% in 2014. Interestingly, as noted by Thorton (2016), data show that Indonesia was ranked $6^{\text {th }}$ in the world in terms of women serving as a senior manager, at $36 \%$, after Russia (45\%), the Philippines (39\%), Lithuania (39\%), Estonia (37\%), and Thailand (37\%).

The phenomenon of women's increasing participation in both education and the professional sector is interesting when related to the demographic bonus that Indonesia is expected to experience. In that era, the dependent age group would shrink, and the economy would have the potential to grow faster, and it is hypothesized that women's increased participation in higher education could also support the demographic bonus phenomenon. However, it is not necessarily this straightforward. When women enter the professional sector, they bear double responsibilities: unpaid domestic tasks and paid work outside the home. Particularly for women who have the status of postgraduate education, as higher education becomes an investment for a better livelihood.

In Indonesia, financing for postgraduate studies is quite varied. Both male and female students generally had support either from private funds (such as their families or their own savings) or from scholarships (both Indonesian and international). The Indonesian government has set aside a large budget for scholarships for young people who are expected to make a contribution to Indonesia, either in the more immediate demographic bonus moment or Indonesia's future in general. However, it seems that not all recipients can have a real contribution.

In order to enhance the demographic bonus potential, we need more people, both male and female, in the field of development.

\subsection{Research Objective}

To find out future projections of Indonesian women with higher education.

\subsection{Research Questions}

1. What is the background of women in Indonesia currently pursuing postgraduate education?

2. Will they work in their field of study after graduation?

3. Do they choose to work after marriage?

\section{Research Methods}

\subsection{Research Approach}

The main aim of this research is to understand whether and how women with postgraduate degrees in Indonesia contribute to the economy, particularly in terms of the demographic bonus, which is expected to occur by 2030 . The study used qualitative methods, which "attempt to produce deeper meaning toward the facts of recorded behavior and try to get qualitative data: theoretically richer in observations that aren't easily reduced" (Babbie, 2004).

This research used descriptive methods, most widely used in the social sciences, as they help to describe a situation or event (Babbie, 2004). According to Neuman (2006), "Descriptive research aims to describe in words or numbers to answer research questions such as who, when, where, and how."

\subsection{Sampling Technique}

The author used purposive sampling for this study. As Neuman (2006) says, "Purposive sampling is a nonrandom sample in which the researcher uses a wide range of methods to locate all possible cases of a highly specific and difficult to reach population." Purposive sampling was used to get information about women who had reached postgraduate level, and thus, informant selection could not be done randomly.

The criteria for inclusion in the study were as follows:

1. Indonesian women,

2. from 20 to 35 years old,

3. current postgraduate student or postgraduate alumna, and

4. independent financing or scholarship. 


\subsection{Data Collection Techniques}

There were two techniques for data collection: interviews and questionnaires. Fifty-five respondents completed questionnaires, and follow-up interviews were conducted with 11 of them.

A qualitative interview is an interaction between the interviewer and the respondent, whereby the interviewer has a general plan to get the information, but there is no specific sequence for the questions to be asked, and the interview schedule can be tailored to meet the needs of the research topic. Therefore, the questions in this study focused on the respondents' backgrounds, their motivations for studying, their eagerness to use their knowledge in the future, and their future prospects in terms of employment. Of the 11 interviewees, five had graduated from universities in Indonesia (four from the University of Indonesia in Jakarta and one from the University of Airlangga in Surabaya), whereas six had studied abroad: at Monash University (Melbourne), the Australian National University (Canberra), DHBW Ravensburg (Karlsruhe), Osmania University and The English and Foreign Languages University (Hyderabad), Jawaharlal Nehru University (New Delhi), and the Politecnico di Milano (Milan).

A questionnaire was used to gain an overview of the characteristics of the study population, women with higher education in Indonesia, and 55 responded. For those living outside the country, the data collection was done via e-mail. The demographics of the 55 respondents are as follows:

- $45 \%$ of respondents were aged $20-25$ years, with 38\% aged 26-30 years.

- $49 \%$ were Masters' students.

- $28 \%$ were funded by their parents, $23 \%$ paid from their own savings, and the remaining $41 \%$ received scholarships.

\subsection{Data Analysis Techniques}

Cresswell (2009) states that the data analysis process as a whole is an attempt to interpret data, either text data or images and can include the following steps:

1. Process and prepare data for analysis, through the development of an interview guide, and transcription of the interviews.

2. Read through the data to familiarize oneself with the contents and overall meanings of the data.

3. Data coding, by highlighting important themes in the interviews.

4. Description of the respondents.

5. Interpretation of data.

\subsection{Validity and Reliability}

In order to improve the validity and reliability of the data, this study used data triangulation, by comparing the results of the interviews with those of the questionnaires (Krefting, 1991). Qualitative research often involves data triangulation through comparing the results from the different sources of data (Cresswell, 2009).

\section{Results}

\subsection{Interviews}

\subsubsection{Postgraduate education is important to women}

According to data from the Indonesian Central Bureau of Statistics (Badan Pusat Statistik, 2015), women's participation in higher education has increased, and the interview results underscore this. The 11 respondents considered higher education essential for humans and believed that this applied to both men and women. Respondents gave the following reasons for why women need higher education:

a. for equal treatment and opportunities for men and women,

b. intelligent and educated women are expected to be good educators for their children and families,

c. knowledge used to find better jobs,

d. postgraduate women will be honored within society,

e. to be more expert and specialized in their field,

f. to keep up-to-date with scientific developments, 
g. the need for education becomes the primary point for women in this globalization era, and

i. education serves to reduce the potential for social conflict.

\subsubsection{Informants are mainly self-financed students}

Among the 11 informants, four were recipients of scholarships (two LPDP awardees and two Indian government scholarships), whereas the remaining seven were self-financed. This shows that Indonesian women are eager to continue their studies. Of the seven non-scholarship students, three had applied for several scholarships before finally deciding to self-fund.

In terms of financing for scholarships, the Indonesian government provided around 3 trillion rupiah in 2017. It was assumed when the funding was given by the Indonesian government for overseas study that recipients would return to Indonesia directly after completion of their studies and contribute to the economy, as a return on the investment. All informants supported this notion, as seen in the comments as follows:

a. When the students return to Indonesia, the government would have to respect their work (e.g. scientific discovery), as incidents where scientific research from Indonesian often ignored due to various political reasons that are not constructive creating big disappointment.

b. Scholarship funds come from taxes, but there must be a clear scheme of scholarships alumni empowerment, and the government should be able to provide welfare for those who are able to work and making a real contribution.

c. Actually no matter where the place (country) we work, the point is giving benefit for Indonesia. Unfortunately, LPDP has given limited time permission to be apprentice after finishing study. LPDP only grant permission a year internship. Some states that if they get longer time to working abroad - at least 2-3 years in the good office related their field - it could give more benefits while return.

$\mathrm{d}$. This has been a consequence of Indonesian government scholarship recipients. If you disagree, so should choose another way such self-finance or other scholarship programs.

\subsubsection{Working after marriage is a must}

Having a good job or being involved in any professional sector is seen as the goal of pursuing postgraduate education. Nine of the 11 respondents agreed that women's involvement in the professional sector after marriage was for self-actualization and to support the economic needs of their families. Some of the reasons given for why women keep working after marriage are as follows:

a. In addition to self-actualization and support the family economy, another factors driving women to work is to help their parents economic.

b. Women working after marriage because they have no choice. In conditions of difficult economic demands, women have to work to help her husband.

c. By working, women can expand the network; open the mind to new things.

\subsubsection{By working, women can contribute toward the demographic bonus}

Women are expected to play an important role in the economic growth related to the demographic bonus in Indonesia. Alongside the growth of women's participation in higher education is the growth of women's wish to be involved in the professional sector.

Six of the 11 respondents agreed that in order to maximize the demographic bonus, Indonesian women have to work to enable the economy to grow faster. However, this cannot be said to be representative of the respondents as a whole, as it accounts for just over half the sample. Thus, it seems that Indonesian women, as represented by the respondent sample, still feel torn about whether women working in the professional sector contributes to the demographic bonus or not. Some of the reasons are given as follows:

a. Indonesian women have to keep contributing in the professional sector and remain their main duty as a housewife as well.

c. The government should take opportunity of the demographic bonus with education quality improvements for women at various levels of occupation.

e. However, the company has to provide appropriate compensation for women in terms of working hours and maternity leave. For example, some private companies just granted two months for pregnant leave or even less, it's unfair though.

\subsection{Questionnaire}

1. Reason for pursuing postgraduate education?

- $60 \%$ want to improve their expertise in their field. 
- $19 \%$ want to become lecturers.

2. Do respondents believe that they will be using their current study knowledge for the next 10 years?

$-88 \%$ believe that they will.

3. Will they work after marriage?

- $84 \%$ answered yes.

4. Likelihood of leaving their job to focus on domestic tasks only?

- $60 \%$ feel sure that they will be able to balance both work and domestic tasks.

$-23 \%$ will leave their job to focus on domestic tasks only.

5 . Why should women work after marriage?

- $72 \%$ believed women should keep working for self-actualization.

6. What if your husband prefers that you focus on domestic tasks only?

- $64 \%$ stated that they would convince their spouse that they could balance their time between the domestic and professional sectors.

$-7.5 \%$ would choose to sacrifice their career to please their spouse.

\section{Discussion}

The results from the questionnaires seem to support the data obtained through interviews, as seen as follows:

1. Postgraduate education is important for women

- $60 \%$ pursued postgraduate study because they wanted to become experts in their field.

2. Most respondents are self-financed

- $28 \%$ were funded by their parents, whereas $23 \%$ paid out of their own savings.

3. Working after marriage is a must

- $84 \%$ of respondents chose to keep working after marriage;

- $72 \%$ would keep working after marriage for self-actualization.

4. By working, women contribute toward the demographic bonus

- $64 \%$ would convince their spouse that they could balance the domestic and professional sectors;

- $60 \%$ felt able to balance the domestic and professional sectors.

\subsection{Naïve Consciousness Phase in Indonesian Women}

Indonesia is an appropriate site for research on women increasing their access through higher education as a form of consciousness. In this instance, women have become aware of the importance of education as a bridge to a variety of things, including knowledge, better jobs, contributing to their country's economy, and contributing to social change.

Along with this, the consciousness can create increased awareness of society's problems. Thus, women can use education as a means to avoid ignorance and poverty.

This aligns with Paulo Freire's idea of liberating education. As one of the most influential thinkers and practitioners of the $20^{\text {th }}$ century, in his book Pedagogy of the Oppressed (Freire, 1973), Freire proposed a theory of awareness, or conscientizacao, an understanding of the real situation being experienced by students. Although the ultimate goal is systemic change, Freire saw "awareness" as the core of education.

Freire divided human consciousness into magical consciousness, naïve consciousness, and critical consciousness. This research suggests that Indonesian women are at the level of naïve consciousness, whereby people have some awareness of the problems in their society, but they feel caught in a dilemma: between fighting and surrendering to the system, between being spectators and actors, and so on (Freire, 1973).

In other words, the liberal community, which is Indonesian women in this context, realizes the political and economic problems in society, but for them, education is completely removed from these problems. Education prepares students for entry into the problematic system, but does not suggest ways to fix the system itself.

Thus, when people maintain the status quo, attempting to gain higher education within a problematic system, it is not what the country needs. Rather, Indonesia needs higher education to assist students to understand the causes of the problems in the system in order to get the greatest potential from the demographic bonus. Hence, this paper argues that what we need is a bigger role for the development sector. 


\subsection{The Importance of Having a Job Related to the Study Major}

Even though they are highly educated, Indonesian women do not necessarily see their professional role as aligning with their field of study. In the interviews, most agreed that they could contribute in diverse ways, not only working in their study fields, although in the questionnaires, $88 \%$ felt sure their current study majors will be useful for the next 10 years. In other words, Indonesian women have a strong conviction that their knowledge will be useful in the future, even if not involved in a job that relates to their study major.

However, finding jobs in a relevant industry is one of the most important factors in determining the success of an institution. An educational facility can be deemed successful if all or most of the graduates can be quickly absorbed into jobs in their field and its strata ranking, either on local level, nationally or internationally (Sadjad, 2002).

Relevance is a complex but systematic and measurable notion if approached conceptually and operationally from a user's perspective. Quality, relevance, and competence are the three higher education aspects that interrelate and directly contribute to improved competitiveness in the field of human resources. Thus, getting a job based on one's study major becomes important (Muhson et al., 2012).

The analogy for this is "the right man in the right place". We have an output of what has been learned over the years, which is our expertise. Employment in sectors that are irrelevant to our study majors could lead to increased unemployment and a growing social gap. For example, if a majority of law graduates are currently working in the banking sector, economics graduates lose the chance to work in their field, and they have less chance of taking over law graduates' jobs, as they are not sufficiently qualified.

\subsection{Women Should Work to Accelerate Economic Growth}

The interview results regarding the demographic bonus show the diversity of opinions, with an almost even split between those who believe that Indonesian women have to work to enable the Indonesian economy to grow faster and those who disagree with the notion. Below are the rationalizations of the respondents who disagreed with the notion that women can support economic growth acceleration:

a. I am not sure, I agree women do work (for women who really want to work) but I am not sure as well as all women work also contributes to increased rates of demographic bonus.

b. I haven't yet to find a logical reason, the relationship between women who work with increased economy rates of the country. I think what needs to be improved is entrepreneurial Indonesian, so unemployment will absorb.

c. I disagree because of work or not is optional. Back to the women's interests itself, what the actual goal for works.

The diversity of opinion highlights two things. First, highly educated women do not yet fully understand the demographic bonus phenomenon, and second, they are apathetic about it, either ignoring it or maintaining the status quo.

The demographic bonus generation should understand that it represents an opportunity to improve the condition of Indonesia, although the media has questioned whether the era should be seen as a gift or a disaster. If the demographic bonus is not managed properly, it could be a demographic disaster, increasing Indonesia's social problems and negatively affecting its welfare.

In order to emphasize the empowerment potential of highly educated women in the demographic bonus, the following three principles should be embraced:

1. Equality of rights for women and men must be enshrined as a fundamental principle. Legal, economic, political, and cultural barriers that hinder this should be identified and removed through comprehensive policy reforms and strong affirmative action.

2. Women must be regarded as agents and beneficiaries of change. Investing in women's capabilities and empowerment is the surest way to contribute to economic growth and overall development.

3. The ever-gendered development model, though aiming to widen choices for both women and men, should not predetermine how different cultures and societies exercise these choices. What is important is that equal opportunities of choice exist for women and men (Singh, 2011).

On the basis of Baij Nath Singh's argument above, it is clear that Indonesia needs women as both agents and beneficiaries of change. In order to maximize economic growth, highly educated women, and particularly women who received scholarships from the Indonesian government, should have a role in the public sector. Along with this, women should be working in fields related to their study majors.

\section{Suggestions}

a. In order to maximize the demographic bonus in Indonesia, the government should make stricter rules for 
scholarship requirements. Scholarship selection teams must ensure that scholarship recipients not only return to Indonesia but also make a real contribution to the country.

b. Women in tertiary education should get more information about the importance of their involvement in the demographic bonus moment.

c. To equalize opportunities to access higher education abroad, the Ministry of Education or Ministry of Research Technology and Higher Education should provide foreign language training for poor students who have not been able to access training or expensive foreign language tests.

\section{Conclusion}

The reasons respondents gave for pursuing postgraduate education included wanting to gain expertise in their field, self-actualization, and helping their family economically. Along with this, women were aware that postgraduate education could help them gain recognition and better jobs. Therefore, they were willing to save to self-finance their postgraduate education if they did not receive scholarships. This shows their willingness to gain higher education, realizing that they could get a better job that would result in a higher quality of life for their family in the future.

In terms of marriage, the majority (84\%) said they will work after marriage. When asked about balancing their professional and domestic responsibilities, $60 \%$ of women felt sure that they would be able to divide their time between the two, whereas $23 \%$ left the professional sector to focus on the domestic sector only. When asked what would happen if their spouse wanted them to quit their jobs to remain at home, $64 \%$ of respondents stated that they would convince their spouse that they could divide their time between the domestic and professional sectors, whereas $7.5 \%$ said they would sacrifice their career to please their spouse.

When asked about the demographic bonus phenomenon, six of the 11 interview respondents agreed that women should work to help the economy to grow faster. However, the respondents did not seem to have realized the importance of their role in achieving the demographic bonus and improving Indonesia's situation.

One possibility is that these women are apathetic about the condition in their country, including the demographic bonus. This could be because they focus on their own work in order to support their family's economic needs, because women often bear a double burden of their domestic and professional responsibilities. Alternatively, the apathy could occur because of a lack of information by the government regarding the demographic bonus phenomenon so that postgraduate women have felt no need to contribute to it. Thus, they may know about the demographic bonus superficially, with no understanding that the productive age potential could support the acceleration of economic growth.

\section{References}

Babbie, E. (2004). The Practice of Social Research (10 ${ }^{\text {th }}$ ed). USA: Wadsworth/Thomson Learning Inc.

Badan Pusat Statistik. (2015). Tren Ketenagakerjaan dan Sosial di Indonesia 2014-2015. Indonesia: ILO.

Creswell, J.W. (2009). Research Design Qualitative, Quantitative, and Mixed Methods Approaches. United Kingdom: Sage.

Freire, P. (1973). Education for Critical Consciousness. USA: Continuum.

Krefting, L. (1991). Rigor in Qualitative Research: The Assessment of Trustworthiness. American Journal of Occupational Therapy, 45(3), 214-222.

Muhson, M et al. (2012). Analisis Relevansi Lulusan Perguruan Tinggi dengan Dunia Kerja. Yogyakarta: Universitas Negeri Yogyakarta.

Neuman, W.L. (2006). Social Research Methods: Qualitative and Quantitative Approach. USA: Pearson.

Sadjad, R.S. (2002). Paradigma Baru Pendidikan Tinggi Untuk Menciptakan Sumber Daya Manusia Unggulan. Makassar, Hasanuddin University. Dept of Electrical Engineering.

Singh, B.N. (2011). Economics of Women Education and Empowerment. India: Abhijeet.

Thorton, G. (2016). Women in Business, New Perspectives on Risk and Reward. Grant Thornton International Ltd.: London, UK. 